The University of San Francisco

USF Scholarship: a digital repository @ Gleeson Library |

Geschke Center

Economics

College of Arts and Sciences

2014

\title{
Do in-Kind Transfers Damage Local Markets? The Case of TOMS Shoe Donations in El Salvador
}

Bruce Wydick

University of San Francisco, wydick@lucas.usfca.edu

Elizabeth Katz

University of San Francisco, EGKATZ@USFCA.EDU

Brendan Janet

Follow this and additional works at: http://repository.usfca.edu/econ

Part of the Economics Commons

\section{Recommended Citation}

Bruce Wydick, Elizabeth Katz \& Brendan Janet. Do in-kind transfers damage local markets? The case of TOMS shoe donations in El Salvador. Journal of Development Effectiveness Volume 6, Issue 3, 2014. DOI: 10.1080/19439342.2014.919012

This Article is brought to you for free and open access by the College of Arts and Sciences at USF Scholarship: a digital repository @ Gleeson Library | Geschke Center. It has been accepted for inclusion in Economics by an authorized administrator of USF Scholarship: a digital repository @ Gleeson Library $\mid$ Geschke Center. For more information, please contact repository@usfca.edu. 


\title{
Do In-Kind Transfers Damage Local Markets? The Case of TOMS Shoe Donations in El Salvador
}

\author{
Bruce Wydick* \\ Elizabeth Katz ** \\ Brendan Janet****
}

March 12, 2014

Key Words: In-kind donations, randomized trial, shoes, El Salvador, impact studies, philanthropy

\begin{abstract}
We carry out a cluster randomized trial among 979 households in rural El Salvador to test whether shoe donations exhibit negative impacts on local shoe markets. Households in half of our communities were given a pair of children's shoes at baseline (treatment communities), while all households were given coupons that could be used for shoe purchases at a local shoe store. Although point estimates on coupon redemption and difference-in-difference estimations indicate shoe purchases to be slightly lower among households receiving the donated shoes, we find no statistically significant difference in market shoe purchases between treatment and control households.
\end{abstract}

*Wydick, Professor, Department of Economics, University of San Francisco, 2130 Fulton Street, San Francisco, CA 94117-1080, e-mail: reydick@usfca.edu (corresponding author); ***Katz, Associate Professor, Department of Economics, University of San Francisco, 2130 Fulton Street, San Francisco, CA 94117-1080, e-mail: egkatz@usfca.edu; **Janet, Field Research Consultant, University of San Francisco, e-mail: bjaneto@gmail.com. We would like to thank Flor Alicia Calvo, Zachary Intemann, Nicole Shevloff, and the directors and staff of World Vision El Salvador for extensive help during field research. We thank the University of San Francisco's graduate program in international and development economics and TOMS Shoes for support and funding of fieldwork. 


\section{Introduction}

Development and relief organizations who donate in-kind goods to the poor in developing countries face increasing criticism that in-kind donations may negatively impact producers and retailers in local markets, thus undermining long-term development. While donations may have a positive direct impact on recipients, in significant quantities they also may reduce local prices to the detriment of suppliers. ${ }^{1}$ Moreover, in a context in which prices are relatively sticky, even limited donations may curtail purchases from domestic sellers. The purpose of this research is to try to rigorously ascertain if shoe donations to low-income countries undermine local markets in this way.

We study the impact of shoe donations on local markets via a randomized trial in which we obtained data on 5,607 individuals in 979 households across 18 communities in El Salvador using baseline and follow-up surveys. Our experiment was carried out in four of World Vision International's Area Development Program (ADP) districts. Approximately 56\% of these households belong to nine communities in which households received a pair of children's canvas shoes at the beginning of our study. The $44 \%$ of households in the remaining nine communities functioned as a control group and received a pair of the shoes only after the follow-up survey.

Every household, in both treatment and control groups, received a pair of coupons for shoe purchases that could be redeemed in a local shoe store. The donated shoes used in our study are a black canvas children's loafer. Because it was unclear whether the donated shoes in our study would substitute in the market for less expensive or more expensive shoes, we analyze the impact of shoe donations on both of these markets. Hence one of the coupons was valid for inexpensive shoes, costing $\$ 10$ or less, while the other coupon was valid for more expensive shoes, costing more than $\$ 10$ but less than or equal to $\$ 20$.

We estimate the impacts on local shoe markets using two methods. First we look at differences in coupon redemption rates between treated and control households in our sample to examine the impact on markets for both less-expensive and more-expensive shoes. Second we use a difference-in-differences approach using reported shoe purchases by households for each member of the family to examine whether, as a result of our intervention, shoe purchases for children aged 6 to 12 (compared to shoe purchases for other members of the family in treated households) declined relative to control households. This provides a second measure of market impact since the donated shoes were intended for children in this age group. 
In order to mitigate problems of over-testing, researcher bias, data mining, and multiple inference, we created a pre-analysis plan of all of the hypotheses, methodology, and regression specifications used in this research. These were registered and time-stamped in a hypothesis registration at the MIT Jameel Poverty Action Lab before any data analysis occurred. The advantage of this hypothesis registration, from a scientific point of view, is that as researchers we were thus able to "tie our hands" in the analysis of our data. In this way, our research could be carried out in the most transparent manner possible and regression specifications could not be skewed toward the direction of more or less favorable results. Thus the hypotheses, general methodology, and even the detailed econometric specifications that we present in our paper conform to that which is listed in our JPAL hypothesis registry, which can be found online. ${ }^{2}$

\subsection{Existing Literature}

Evidence in the literature regarding the impact of development aid more generally has offered mixed reviews at best regarding its long-run impact on economic development. Doucouliagos and Paldam (2005) carry out a meta-study of 97 research papers on the impact of aid in developing countries and find that at best there seems to be a small impact of aid on economic growth. Easterly et al. (2003) and Easterly (2006) also report little positive association between aid and economic growth in developing countries. Exploring the "Black Box" of foreign aid, Bourguignon and Sundberg (2007) conclude that many forms of aid, including gifts in kind, are often ill-conceived, do not constitute an optimal use of resources, and that the relationship between aid and development is fragile and tenuous at best. In her bestselling book, Dead Aid, Moyo (2009) contends that most types of international aid undermine growth by replacing domestic markets, create poor incentives for government officials, retard the development of functional political systems and markets, and in the process create their own development traps.

In contrast, however, Collier (2006) argues that sub-Saharan Africa would have fared far worse during the decades of low growth without foreign aid programs. Dalgaard, Hansen and Tarp (2004) Minoiu, Reddy (2010), and Clemens, Radelet, and Bhavnani (2004) find that foreign aid promotes generally positive long-run effects on economic growth. However, the more nuanced conclusion from this set of papers is that any positive impact on economic growth highly depends on context and type of aid.

Research that studies the impact of development aid in the form of in-kind donations has generally found that, while potentially benefiting recipients, in-kind donations have a negative 
impact on local markets. Some of this literature has looked at the impact of food donations on local economies. Employing a seemingly unrelated regression model that uses monthly data from three markets and three commodities, Tadesse and Shively (2010) study food aid shipments in Ethiopia over a 10-year period. Their results indicate that food shipments in the previous year reduced prices in each of these producer and consumer markets. Interestingly, they find a detrimental effect on local prices and local food production particularly when shipments exceed the $10 \%$ threshold of local production; below this level the negative impacts of in-kind food aid appear to be benign. They conclude that food shipments need to be undertaken more carefully, and perhaps restricted in cases where in-kind food donations replicate domestically produced commodities.

There are two papers preceding this research that examine the impact of in-kind apparel donations on the development of the apparel sector; both study effects in Africa. First, Brooks and Simon (2012) provide an extensive review of the phenomenon of used clothing imports into Africa and its relationship to the development of the apparel sector, but contend that data availability makes causal impact between the two difficult to identify. Frazer (2008) examines the impact of used clothing imports in sub-Saharan African countries, asking why bottom-round textile production has not emerged as a leading sector of development in Africa as it has in other regions of the world such as Asia. He finds that used apparel donations have had a strongly negative impact on domestic apparel producers in Africa. Using an instrumental variable strategy that exploits geographic differences between countries, Frazer finds that while imports of cheap clothing benefit consumers, he estimates that used-clothing donations accounted for a $40 \%$ decline in production and a 50\% decline in employment in the apparel industry.

\section{The Impact of In-Kind Donations on Market Purchases: Theoretical Framework}

There are a number of conceivable ways that in-kind donations could affect local household consumption patterns and domestic markets. How donations affect household consumption patterns depends on the nature of preferences given by the household's utility function. For example, suppose that households have Cobb-Douglas utility and maximize utility over $N$ goods each denoted by $X_{i}$, where $\sum_{i=1}^{N} \alpha_{i}=1$

$$
U_{H H}=\prod_{i=1}^{N} X_{i}^{\alpha_{i}}
$$

subject to the budget constraint $\sum_{i=1}^{N} p_{i} X_{i} \leq Y$, where $p_{i}$ is the price of each good and $Y$ is income, with $N$ associated first-order conditions 


$$
\frac{\partial U_{H H}}{\partial X_{j \neq i}}=\alpha_{j} X_{j}^{\alpha_{i}-1} \prod_{i \neq j}^{N} X_{i}^{\alpha_{i}}-\lambda p_{i}=0, \forall i
$$

Here, an in-kind donation of one unit of a given good $j$ increases the marginal utility of other goods relative to $\operatorname{good} j$, and hence household purchases of good $j$ ought to fall. This is the theoretical case that pertains to those who contend that in-kind donations should exhibit negative effects on domestic producers and suppliers of good $j$.

There are, however, other possible impacts from in-kind donations on household consumption patterns. Suppose that households exhibit preferences for equality in consumption between members of the household, for example between each of the household's children. Each of the $M$ members of the household consumes $N$ goods, and suppose household utility exhibits Cobb-Douglas preferences between household members for any particular good, but utility is additive across goods such that

$$
U_{H H}=\sum_{i=1}^{N} \prod_{k=1}^{M} X_{i k}^{a_{i k}}
$$

where $\sum_{i=1}^{N} a_{i k}=1$, with associated first-order conditions

$$
\frac{\partial U_{H H}}{\partial X_{h, j}}=a_{h, j} X_{h, j}^{a_{i}-1} \prod_{k \neq h}^{M} X^{a_{i}}-\lambda p_{i}=0, \forall i * k
$$

In this case if one member of the family $h$ receives an in-kind donation of some good $j$, it increases the marginal utility of the household for other members of the family receiving that same good $j$. Here we would expect additional household purchases of the in-kind donation good $j$ to increase relative to other goods, these new purchases of good $j$ then allocated to family members who did not receive the donation. An example of this could conceivably occur with shoe donations, where one child receives a pair of shoes through an in-kind donation, and parents desire to reallocate purchases from other goods toward providing shoes for other siblings who did not receive the donation.

A third case may occur in which the in-kind donation has no marginal relation to the utility of other goods consumed by the household. An example might be laptop computer donation to households who view a computer as a new product with no substitutability or complementarity with existing products in the household consumption portfolio. Consider a utility function similar to (1), in which other goods affect the marginal preferences of other goods except that we now include an additively separable good $Z$, a new donation-in-kind good:

$$
U_{H H}=\prod_{i=1}^{N} X_{i}^{\alpha_{i}}+Z^{\beta}
$$


Here, our first-order conditions are identical to the first case, except for good $Z$ for which

$$
\frac{\partial U_{H H}}{\partial Z}=\beta Z^{\beta-1}-\lambda p_{Z}=0 .
$$

Because preferences between good $Z$ and $X_{i}$ are additively separable, we would not expect donations to exhibit any positive or negative effects on domestic markets for the latter, nor for good $Z$, since it would not be consumed by the household anyway given sufficiently high $p_{Z}$. In the example of the computer donation, while receipt of the computer might increase household utility, it has no effect on the budget allocation of the household.

\section{Experimental Setting and Estimation Equations}

\subsection{Field Site}

The experiment was carried out in tandem with the TOMS shoe-giving program that functions as a key part of the company's social mission. TOMS promises customers to give a pair of shoes to a needy child one-to-one for every pair of its shoes purchased by customers. The donated shoes were similar to the shoes that TOMS typically sells to its regular customers. The shoes were black slip-on loafers with a canvas upper containing an elastic band for comfort and flexibility on the upper ankle. The shoes have a durable synthetic rubber sole.

Our fieldwork was carried out in four World Vision's Area Development Program (APD) regions in El Salvador. Within each of these four ADPs we worked with four to six communities, randomly choosing half of the communities to receive the children's shoes at baseline. The remaining communities received the shoes at follow-up.

All of the participating communities in the TOMS were very similar within each of their respective ADP regions; indeed there were only slight differences even across regions. All municipal centers had small stores (usually operated out of homes), schools, health clinics, and home-restaurants. Nearly every community had its own school with reasonably adequate resources (2-4 teachers, books and materials, desks, etc.) Every municipality had a functioning health clinic with usually one doctor and multiple Promotores de Salud (Health Promoters). The Health Promoters were responsible for traveling to communities to check on patients. Our communities tended to be similar in levels of asset ownership, materials used for homes, type of agricultural work, and cultural norms. Adolescent boys typically worked in subsistence and cash crop agriculture; adolescent girls frequently collected water, carried out numerous household chores, and watched younger children. 
Throughout the duration of the study, we observed and informally interviewed people about the culture of shoe wearing among children. El Salvador is not a country in which children do not own shoes. Nearly every child owns a pair of shoes or sandals, and in our sample $88 \%$ of children owned two or more pairs of shoes, but this was concentrated at a low level of shoe ownership; in our study approximately $80 \%$ of children owned either two or three pairs of shoes, one often being a very inexpensive pair of flip-flops or sandals. Indeed, it appeared that most of the families, even the very poor ones, could afford a pair of shoes or sandals. Only two children from age 6 to 12 in our study out of the 1,492 studied had no shoes at all at baseline.

Almost all of the shoe vendors with whom we contracted in our experiment sold inexpensive imported footwear. Some communities would acquire footwear from NGO donations, government handouts, or would purchase with remittance money. When we observed children or adults walking barefoot, we learned that it was rarely because they didn't own a pair of shoes, but instead because they preferred to walk barefoot.

The response from children was strongly positive regarding the TOMS shoe donations: $90 \%$ of children who received the shoes wore them, with mean use at 4.54 days per week. The modal response was 7 days per week (see Table 1), indicating that although shoe ownership was prevalent, the shoes clearly filled a void. Children also reported that they liked the shoes. Approximately $92 \%$ of children in the treatment group reported that they liked the shoes at follow-up, 3\% said they liked them "a little bit" and 4\% didn't like the shoes. (During the study we heard some boys comment that they did not like the TOMS shoes because they looked like "pregnant women shoes.”) Mothers frequently reported to us that the TOMS shoes would wear out very quickly due to the environment and heavy use by the children. Many parents and children would have preferred to have a sturdier, hiking-style shoe.

Across El Salvador, including our study communities, children are required to wear school uniforms and black dress-shoes to school. Some schools allow children to wear the donated black TOMS shoes, which many children found to be more comfortable than their school shoes. Most children reported taking off their school shoes when they arrive home from school, then playing or doing chores barefoot or with sandals. Playing soccer is a very common activity, and to play, children would typically put on sneakers or the TOMS shoes. Table 2 gives a breakdown of children's activities while they were wearing the donated shoes, where simply wearing the shoes around the house (33.0\%), playing in them (31.4\%), or using them for school $(20.5 \%)$ were the most frequent activities. 


\subsection{Experiment}

The four ADP regions in our study, Nueva Vida, San Julian, Torre Fuerte, and Tierra Nueva, were chosen based on the following criteria: First, our chosen ADPs were to achieve wide coverage of El Salvador in geographical terms. Second, they had to be in areas of extreme rural poverty prevalence. Third, they must not have received World Vision shoe donations in the previous year. All communities had child sponsorship and community development programs operated by World Vision.

The randomization of the treatment and distribution of the shoes was a cluster randomization carried out at the community level within each region after a baseline survey of the treated and control communities. Randomization needed to be clustered at the community level in order to avoid jealousies that would stem from a fraction of households in a community receiving shoes at baseline while others not. Cluster randomization results in a reduction of power, especially in instances when intraclass correlation, $\rho$, is high. We estimated intraclass correlation across communities for shoe purchases during the six months previous to the baseline survey based on a one-way ANOVA, finding $\rho=0.033$, relatively low due to the relative similarity in our communities. Thus the loss in statistical power is relatively minor from the cluster randomization.

Our field experiment randomized the dispersal of the shoes in nine of these communities after the baseline survey, with half of the communities in each ADP randomly assigned to treatment. The follow-up survey was undertaken 3 to 4 months after baseline. Households that formed part of the study in each village were those having children with in the 6 to 12 -year shoe-donation recipient age. Each household with children in the appropriate age range was surveyed in each community. Shoes were distributed to the control communities after obtaining follow-up survey information.

The unit of analysis for our coupon experiment is based on coupon redemption at the household level, while the unit of analysis for our differences-in-differences estimations is for shoe purchases at the individual level within households. The head of households provided the information obtained in the survey. Balancing tests over key household demographic and economic variables between treatment and control communities are presented in Table 1 and include parental education, household size, average household age, log of landholdings, electrification of the household, minutes to the contracting shoe store, home having a dirt floor, number of children under 10 years old, baseline shoe purchases, and ownership of cell phones and 
televisions. There were no statistically significant differences between treatment and control households except for dirt floor (at the $5 \%$ level), indicative of a successful randomization.

In the follow-up data taken 3 to 4 months after baseline survey and intervention, household heads were interviewed to obtain data on shoe purchases, while the second layer of data came from the results of the coupon experiment. In our coupon experiment, we allocated two discount coupons to households in both treatment and control communities: one of which could be redeemed for the purchase of inexpensive shoes costing $\$ 10$ or less, and the other could be redeemed for more expensive shoes, costing more than $\$ 10$ and less than $\$ 20$. In the first two ADP regions, our coupons offered discounts of $\$ 1$ for the former and $\$ 3$ for the latter. In the second two ADP regions, household heads randomly drew coupon discounts of $75 \%, 50 \%$, and 25\% for both types of coupons following the protocol of Meredith, Robinson, Walker, and Wydick (2013). The type of coupon allocated in the second two ADPs was altered to increase the redemption rate over that which was realized in the first two ADPs and estimate how redemption rates varied with the degree of discount, i.e. implicit price. In the same way, one coupon could be redeemed for less expensive shoes, and one for the more expensive shoes.

We worked with local shoe vendors, who were compensated for the redeemed coupons. These shoe vendors operated small stores that specialized in shoes, and in some cases other types of sports clothing and equipment. The vendors turned over redeemed coupons to field researchers, where each coupon was stamped with household information so it could be matched easily to the survey. Thus coupons were either redeemed or not redeemed, and this is the primary measure we use to determine market impacts of the shoe donations. We believe the vendor data to be highly reliable, but we also included a question on the follow-up survey regarding whether the family had redeemed either of the coupons.

As an additional impact estimation strategy, we use a difference-in-difference estimation to examine the difference between purchases of shoes for children (6-12) during the 3-4 months between baseline and follow-up and purchases outside this age group, and then compare this difference between treated and untreated communities. In these estimations we use reported shoe purchase data rather than coupon redemption data. We implement this difference-in-difference estimation because purchases outside of this 6-12 age group should be unaffected by the shoe donation treatment. 


\subsection{Empirical Specifications}

We estimate the empirical specifications as laid out in our JPAL pre-analysis plan and hypothesis registry. ${ }^{3}$ For our first measure of market impact that uses our coupon experiment, we estimate

$$
y_{i j}=\alpha+\boldsymbol{X}_{i j}{ }^{\prime} \boldsymbol{\beta}+\theta T+\mu_{j}+\varepsilon_{i t}
$$

where $y_{i j}$ signifies coupon redemption, $\boldsymbol{X}_{\boldsymbol{i} \boldsymbol{j}}{ }^{\prime} \boldsymbol{\beta}$ are control variables that describe household characteristics, including education of parents, distance to shoe store, average household age, number of young children, and indices of dwelling quality and asset ownership. ${ }^{4} T$ is an indicator of whether the household lives in a treatment community, $\mu_{j}$ is an ADP (region)-level fixed effect (which contains 4-6 communities), and $\varepsilon_{i t}$ is the error term. Market impact is captured by $\theta$. We estimate (4) using the linear probability model. We estimate these equations for both inexpensive (price $\leq \$ 10)$ and expensive $(<\$ 10$ price $\leq \$ 20)$ shoes because there is a question about whether the donated shoes are closer substitutes for inexpensive shoes (e.g. Crocs, flip-flops), or more expensive shoes, such as the kind worn by children to school and church.

For our second measure of market impact that compares purchases across family members and treated/control communities, we estimate the difference-in-differences equation:

$$
y_{i j}=\alpha+\boldsymbol{X}_{i j}{ }^{\prime} \boldsymbol{\beta}+\theta T+\rho T C+\omega C+\mu_{j}+\varepsilon_{i}
$$

where $y_{i j}$ are shoe purchases during the 3-4 month period before follow-up, $T$ represents being in a treated community and $C$ represents being a member of the children's group (age 6-12) that is a target of the shoe donation. We would measure the impact of the donation then by the coefficient $\rho$. Again we estimate (5) via OLS.

\section{Experimental Results}

\subsection{Coupon Experiment}

Simple $t$-tests over differences in coupon redemption for inexpensive shoes between treatment and control communities show that coupon redemption in treatment communities was $32.8 \%$ relative to $33.6 \%$ in control communities using our vendor redemption data, lower where shoe donation occurred, but indicating a statistically insignificant difference in redemption rates $\left(t=0.26, t_{I C C}=0.17\right.$, the latter accounting for intra-class correlation). For expensive shoes, redemption rates were $32.7 \%$ in treatment communities and $35.0 \%$ in control communities, also statistically insignificant $\left(t=0.79, t_{I C C}=0.50\right)$. We tested a further outcome that simply asked 
whether a household redeemed either coupon. The fraction redeeming any coupon in treatment communities was $37.3 \%$ in treatment and $39.4 \%$ in control communities, again a statistically insignificant difference $\left(t=0.67, t_{I C C}=0.43\right)$. Using self-reported redemption data (where 40.2\% of households reported redeeming a coupon compared to $38.2 \%$ from our vendor data) the difference is somewhat larger, $37.8 \%$ in treatment communities relative to $43.5 \%$ in control. The difference is statistically significant in a simple $t$-test at the $10 \%$ level, but statistically insignificant after accounting for intraclass correlation $\left(t=1.79, t_{1 C C}=1.13\right)$.

Figure 3 shows demand curves for inexpensive and expensive shoes, respectively, based on the variable prices in our coupon experiment in the final two ADPs. The dark blue line shows the demand curve at the three different sets of prices (given implicitly by the varying discounts of the randomly drawn coupons), the light blue, control. We do find that households are fairly sensitive to shoe prices, especially for expensive shoes. Figure 3 shows that coupon redemption rates in treatment communities for shoes costing more than $\$ 10$ fall from $89 \%$ to $26 \%$ as the value of the coupon discount decreases from $25 \%$ to $75 \%$. (In control communities, the fall in redemption rates is from $79 \%$ to $27 \%$.) Converting this into a price elasticity of demand yields an average elasticity of -1.06 , larger than the -0.405 demand elasticity reported for similar shoes in Meredith et al. (2013). Figure 3 shows little overall shift in the demand curve based on whether a community received shoe donations at any level of price.

Regression results for the impact on redemption of coupons for inexpensive shoes are shown in Table 2. In the first four columns we show linear probability (LP) model estimations using all four ADPs, both the first two ADPs in which we gave set dollar discounts and the second two ADPs in which households randomly drew a coupon and received either $25 \%, 50 \%$, or $75 \%$ discount on the purchase of new shoes. The first column provides LP estimates without controls, the second column with a full set of controls, and the third and fourth columns provide estimations only for poorer households (homes with a dirt floor) and for households with more than two younger children under age 10. The fifth and six th columns replicate columns 1 and 2 using only ADPs 3 and 4. Point estimates from OLS estimations in columns 1 and 2 (with and without controls) yield identical point estimates, showing that the impact of the donations reduced coupon redemption rates by 2.30 percentage points. The fact that we obtain the same estimates with and without controls appears to indicate the similarity of control variables across our communities and that control variables are very closely orthogonal to treatment assignment. Both estimates are statistically insignificant, and yield no conclusive evidence for a negative impact on local markets. ${ }^{6}$ Estimations for poorer households in column 3 and households with 
young children yield in column 4 similar insignificant impacts as do the final columns 5 and 6 estimated only in ADPs 3 and 4 where the large percentage coupon discounts were offered.

Impacts of the shoe donations on the redemption of coupons for expensive shoes in Table 3 yield similarly negative point estimates on shoe market impact, but point estimates are again small and statistically insignificant. Point estimates from OLS estimations in columns 1 and 2 yield point estimates of -0.033 without controls and -0.022 with controls, respectively. The point estimate of negative market impacts for families with more than two young children appears to be a little bit higher at -0.060, but is again statistically insignificant. Results using only ADPs 3 and 4 in columns 5 and six also yield negative but insignificant point estimates.

Table 4 shows regressions on households redeeming either one or both of the inexpensive shoe and expensive shoe coupons as a function of treated and untreated status and controls. Point estimates for negative impacts on the market are very close across all six columns, ranging from -0.024 to -0.041, but none are statistically significant. Table 5 gives results for self-reported coupon redemption data. The results using the self-reported data show larger effects than our vendor-reported data, although there is only a two percentage point difference between the two redemption rates and the correlation between the two is very strong (0.790). While the impacts in Table 5 are roughly double that of the vendor reported data, they remain statistically insignificant. As a result, we find that in each of our 24 estimates from our coupon experiment, we find point estimates within a very tight range that are indicative of some small negative impact of donated shoes on market purchases of shoes, but none of these point estimates is large enough to obtain statistical significance even at the $10 \%$ level.

\subsection{Difference-in-differences Estimation}

Households were asked in the follow-up survey to record shoe purchases for every individual in the household over the previous three months since the baseline survey. We carry out simple $t$-tests with purchase data on each member of the household to see if reported shoe purchases declined during this period among treated households relative to control households. These tests reveal that $13.8 \%$ of members of households in treated communities purchased shoes within the previous three months of the follow-up survey, compared to $17.4 \%$ of individuals in control communities, a difference statistically significant at the $1 \%$ level ( $t$-value 3.44). When we restrict reported purchases to children between 6 and 12 years, which should be most affected by the shoe donations, the difference is still significant at the $1 \%$ level, $22.3 \%$ in treated communities compared to $29.2 \%$ in control communities ( $t$-value 3.01 ). 
Difference-in-difference estimations that control for individual characteristics and include ADP-level fixed effects reveal lower shoe purchases among children in treated communities that are nearly identical in magnitude to those we estimate from our coupon experiment. These LP difference-in-difference estimates show a decline in the probability of the shoe purchase of -0.041. Adding controls in column 2 yields an estimate very close to this of -0.038. Columns 3 and 4 showing the impacts on market shoe purchases for poor households and households with more young children are just slightly smaller.

The final two columns in Table 5 break down spillovers on shoe purchases for children not only in the age 6 to 12 range who received donated shoes, but for children under six (column 5) and for teenagers age 13 to 19 (column 6). As we might expect, point estimates indicate that the donations likely replaced market shoe purchases more extensively for the younger children, and they range from -0.053 to -0.058 for the age 6 to 12 group and the under six group, respectively. The interpretation of these coefficients is that being a child in a home who received a pair of donated shoes resulted in a roughly 5 percentage point reduction in the probability that a market purchase of shoes was made for that child during the three months previous to the follow-up survey, although none of the estimates are statistically significant. Point estimates for market shoe purchases for teenagers age 13 to 19 are -0.024 and -0.036 without and with controls, respectively. One could interpret this as that the most likely impact of the TOMS shoe donations is that every 20 pairs of shoes donated in a village results in about one less pair of shoes purchased in the market for young children.

In both our experimental and difference-in-difference estimations, we find little evidence that would support the existence of a utility function similar to (2), in which households increase purchases of, for example, shoes in order to provide shoes for children who were not beneficiaries of the donation. Overall, we find more evidence for the utility function given in (1), where donated goods may slightly decrease purchases of the same good in local markets. Although our point estimates are very consistent across specifications and estimation strategies, they are consistently small. Although they fail to reach statistical significance, 30 out of 30 of our estimates point to negative impacts on market purchases in the -2.2 to -7.0 percentage point range. Given a mean in the control of shoe purchases for 6 to 12 year olds of $29.2 \%$ and a standard deviation of 45.5 percentage points, we consistently estimate a drop in the probability of a market shoe purchase of 0.048 to 0.153 standard deviations. We also cannot completely rule out from our results that the household utility function looks similar to that in (3), where the receipt of the donated pair of shoes is viewed as a distinct and new good that increases household 
utility and has essentially zero impact on the marginal utility of both the donated good and other goods across members of the household. However, given the heavy usage of the shoes among recipient children and reported happiness with the shoes, it is clear that their marginal utility is high, leading us to believe that the utility function in (1) is operative and that the donated shoes are likely to be substituting to a small degree for market shoe purchases.

\subsection{Statistical Power and Robustness Checks}

Our treatment involved the free distribution of shoes, a consumer item that we believed to be valuable to our subjects. Given concerns that randomization at the household level could promote jealousies between households, it was preferred by a number of parties to the study that we carry out a cluster randomization at the community level rather than a standard household-level randomization to mitigate this potential problem.

We address this issue and how it relates to the power of our tests in the paper in three ways. First, our estimate of intra-class correlation gives us some basis for carrying out power calculations that account for any clustering of shoe-buying behavior within the communities in our sample. For example, while the standard error for the classical test in difference in proportions is $\left[p(1-p)\left(1 / n_{1}+1 / n_{2}\right)\right]^{\wedge} \mathrm{O} .5$, the standard error including our variance inflation factor (Hedges and Hedburg, 2007) becomes $\left([1+(m-1) \rho]\left[p(1-p)\left(1 / n_{1}+1 / n_{2}\right)\right]\right)^{\wedge} 0.5$, where $m$ is the sample size in each cluster. For our study this means that the standard error in our estimates becomes inflated from 0.0315 to 0.0494, given our (treated) $n_{1}=563$ and (control) $n_{2}=$ 416, $\rho=0.0334$, and our average cluster size $m=45$ households. At $80 \%$ power and alpha $=0.05$, the minimum detectable effect lies 2.8 standard errors from the null $\left(t_{\alpha}+t_{k}=1.96+0.84\right)$. This makes our minimum detectable effect 0.138 or 0.284 standard deviations. We consistently find reductions in shoe market purchases that are about one-third the magnitude of this level.

A reasonable question one might ask is how much difference would an expansion of the sample in our experiment made in obtaining a statistically significant result? In other words, if we were to, for example, double the sample size and number of clusters, how much lower would coupon redemption rates had to have been in the treatment group of this added part of the sample to reject the null of zero impact of the donations on market shoe purchases? Accounting for intraclass correlation, we ran simulations to this end, which indicate for a doubling of clusters and sample size, that non-rejection of the null is robust to a full one-standard-error lower redemption rate in the mean of the treated group of an expanded sample population. In other words, for this doubling of the sample size to result in rejection of the null hypothesis, the mean 
redemption rate in our experiment within the new treated households would have to have be a full standard error lower than in the sample we actually obtained. For the cheap coupon redemption statistic, the treated mean in the new augmented part of the sample would have to be a full two standard errors below the mean in our sample. And in the self-reported data (where coupon redemption is lower among the treated), the treated mean would have to be about 1.6 standard deviations below the mean in our existing sample. Thus even a doubling of the sample size could have allowed for a rejection of the null of no impact, but it is unlikely. Moreover, given the fixed costs inherent to our field design of obtaining the necessary permissions and personnel to carry out local surveys in each community, does not allow for a simple trade-off of smaller clusters for more clusters (communities involved in the study). Given the low intraclass correlation, the balance achieved across household characteristics through the cluster randomization, and the use of the baseline study in the difference-in-difference estimations, it is unlikely that additional clusters (up to any reasonable level of field budget) would have yielded the statistical power to reject the null of zero impact on market shoe purchases.

To check for robustness across different potential treatment assignments in our 18 communities, we carried out a modified version of Fischer's exact test (which is often used on very small samples or in instances with very few clusters) using randomization inference. In a classic use of randomization inference, one would carry out a placebo test to examine the $t$-statistic that corresponds to every permutation of possible placebo treatment. In other words, one considers every possible permutation of treatment assignment, calculating $t$-statics for each hypothetical treatment and control group, and then checks to see if the $t$-statistic of the true treatment assignment falls above the $95^{\text {th }}$ percentile of $t$-statistics in this exhaustive set of treatment permutations. Because our number of clusters is much larger than normal for this exercise, we carried out a simulation in Stata of 1000 random assignments to treatment (where in each of our four World Vision ADP regions, 2-3 communities were randomly assigned to treatment. Based on this simulation, we find that our actual $t$-statistic on our true treatment assignment ranked in approximately the $56^{\text {th }}$ percentile of the set of 1000 placebo simulations in our coupon experiment $t$-tests, our coupon redemption regression ranked in the $64^{\text {th }}$ percentile, and our difference-in-difference regression in the $70^{\text {th }}$ percentile. The result is that the behavior of our treated households falls in the middle of the pack relative to 1000 simulations of false treatment assignment, meaning that despite the relatively low number of clusters, there is no reason to think that coupon redemption or shoe purchases were altered in any significant way by the true (random) assignment to treatment. 


\section{Conclusion}

Our experimental study among 979 households in El Salvador finds modest evidence to support the hypothesis that donated shoes exhibit negative impacts on local shoe markets. We view El Salvador in many ways as an ideal context to test the impact of in-kind donations on local markets because, although there are many children who do not wear shoes out-of-doors, most children do own two or three pairs of shoes, providing greater scope for finding a negative impact on local markets than a context in which shoe ownership, and hence market purchases, are rare. Indeed there are many countries such as El Salvador, which are large recipients of donated shoes and clothing, but where existing ownership of these goods is relatively common compared to developing countries with even lower income levels.

While all of our regression estimates lie in the direction of slightly negative impacts on household shoe purchases, they fail to reach statistical significance, and thus we cannot present conclusive evidence pointing to a negative impact on domestic markets from in-kind donations. We approach our analysis by using two different measures of market impact: measuring relative redemption rates of shoe coupons good in local shoe stores, and by examining whether shoe purchases among children eligible for shoe donations declined relative to others in the household in treated communities versus the same difference in control communities. While simple $t$-tests in our latter estimations reveal significantly lower shoe purchases among households who received shoe donations, after controlling for household and parental characteristics as well as ADP-level fixed effects, we can uncover no statistically significant negative impact on shoe purchases in local markets. 


\section{References}

Bourguignon, F., \& Sundberg, M. 2007. “Aid Effectiveness: Opening The Black Box,” American Economic Review 97(2), 316-321.

Brooks, Andrew And David Simon. 2012. "Unravelling the Relationships Between Used-Clothing Imports and the Decline of African Clothing Industries" Development and Change 43 (6), 1265-1290.

Casey, Katherine, Rachel Glennerster, And Edward Miguel. 2012. "Reshaping Institutions: Evidence on Impacts Using a Pre-Analysis Plan" Quarterly Journal Of Economics 127 (4): $1755-1812$.

Collier, Paul. 2006. "What Can We Expect from More Aid to Africa?." Centre For the Study Of African Economies, Oxford University, Manuscript, May 2006.

Clemens, M. A., Radelet, S., and Bhavnani, R. 2004. Counting Chickens When They Hatch: The Short-Term Effect of Aid on Growth. Center For Global Development.

Dalgaard, C.J., Hansen, H., \& Tarp, F. 2004. "On The Empirics Of Foreign Aid And Growth.” Economic Journal.

Doucouliagos, Hristos, And Martin Paldam. 2005. "The Aid Effectiveness Literature: The Sad Result of 40 Years of Research," Department Of Economics, Working Papers 2005-15, Department Of Economics, University Of Aarhus.

Easterly, William. 2012. "Toms Shoes Buy-1-Give-1 Keeps Surpassing Its Own Record As Worst Charity In Development.” Remarks Posted On Twitter, Https://Twitter.Com/Bill_Easterly /Status/186826099743924227.

Easterly, William, Ross Levine, And David Roodman. 2003. "New Data, New Doubts: Revisiting Aid, Policies, And Growth." Center For Global Development Working Paper Number 26.

Easterly, William. 2006. The White Man's Burden; Why The West's Efforts To Aid The Rest Have Done So Much Ill And So Little Good.” Penguin Press: New York.

Frazer, Garth. 2008. Used-Clothing Donations and Apparel. The Economic Journal. (118) 1764-1784.

Hedges, Larry and Hedberg, E.C. 2009. "Intraclass Correlations for Planning Group Randomized Experiments in Rural Education.” Journal of Research in Rural Education, 2007, 22(10) 1-20.

Makinwa, T. 2012. The Trouble With Toms. Date Of Post: April 10. Retrieved May 1, 2012, From Okay Africa: Http://Www.Okayafrica.Com/Stories/The-Trouble-With-Toms/.

Meredith, Jennifer, Sarah Walker, Jonathan Robinson, And Bruce Wydick (2013. "Keeping The Doctor Away: Experimental Evidence On Investment In Preventive Health Products." Journal Of Development Economics 105 (6) 196-210. 
Minoiua, C., \& Reddy, S. G. 2010. "Development Aid And Economic Growth: A Positive Long-Run Relation.” The Quarterly Review Of Economics And Finance.

Moyo, Dambisa. 2009. Dead Aid: Why Aid is not Working and How There is a Better Way for Africa. FSG: New York.

Nemana, Vivek. 2010. November 12. "A Tryst With Toms" Aidwatch. Stable Url: Http://Aidwatchers.Com/2010/11/A-Tryst-With-Toms/

Shevloff, Nicole. 2013 "Are Shoe Donations Bad Aid? The Impact Of Shoe Donations On Local Demand With Evidence From El Salvador” University Of San Francisco Masters Thesis.

Tadesse, G., and Shively, G. 2010. "Food Aid, Food Prices And Producer Disincentives In Ethiopia. American Journal Of Agricultural Economics, 4-5.

Wadams, Nick. 2010. "Bad Charity: And All I Got Was This Lousy T-Shirt" Time Magazine, May 12, 2010. http://Content.Time.Com/Time/World/Article/ 0,8599,1987628,00.Html

Watkins, T. 2012, January 17. How Oliberte, The Anti-TomS, Makes Shoes and Jobs in Africa. Online blog post. Retrieved May 2012, from GOOD-Business: http://www.good.is/post/how -oliberte-the-anti-TOMS-makes-shoes-and-jobs-in-africa 


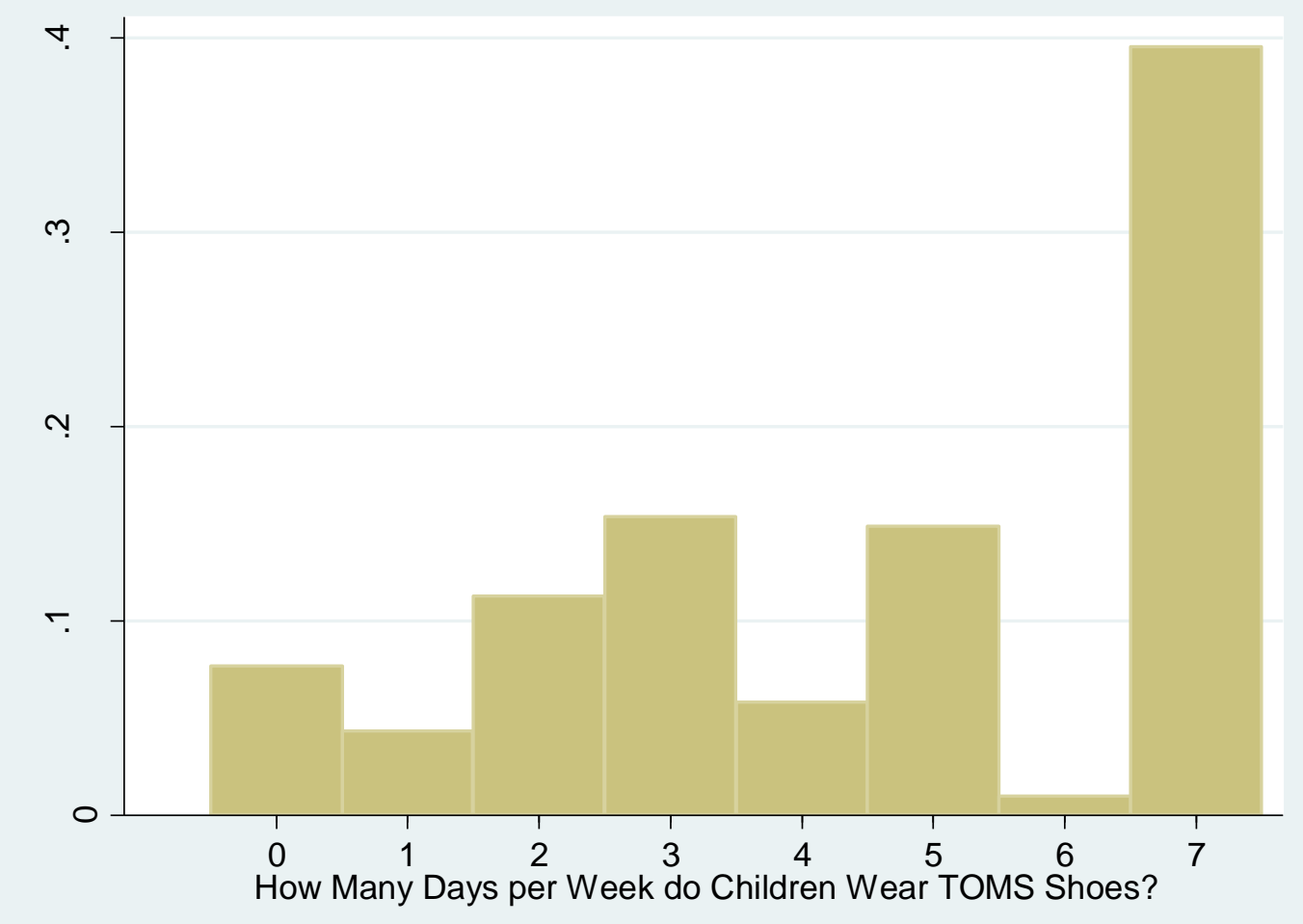

Figure 1: Days per Week Children Wear Donated Shoes

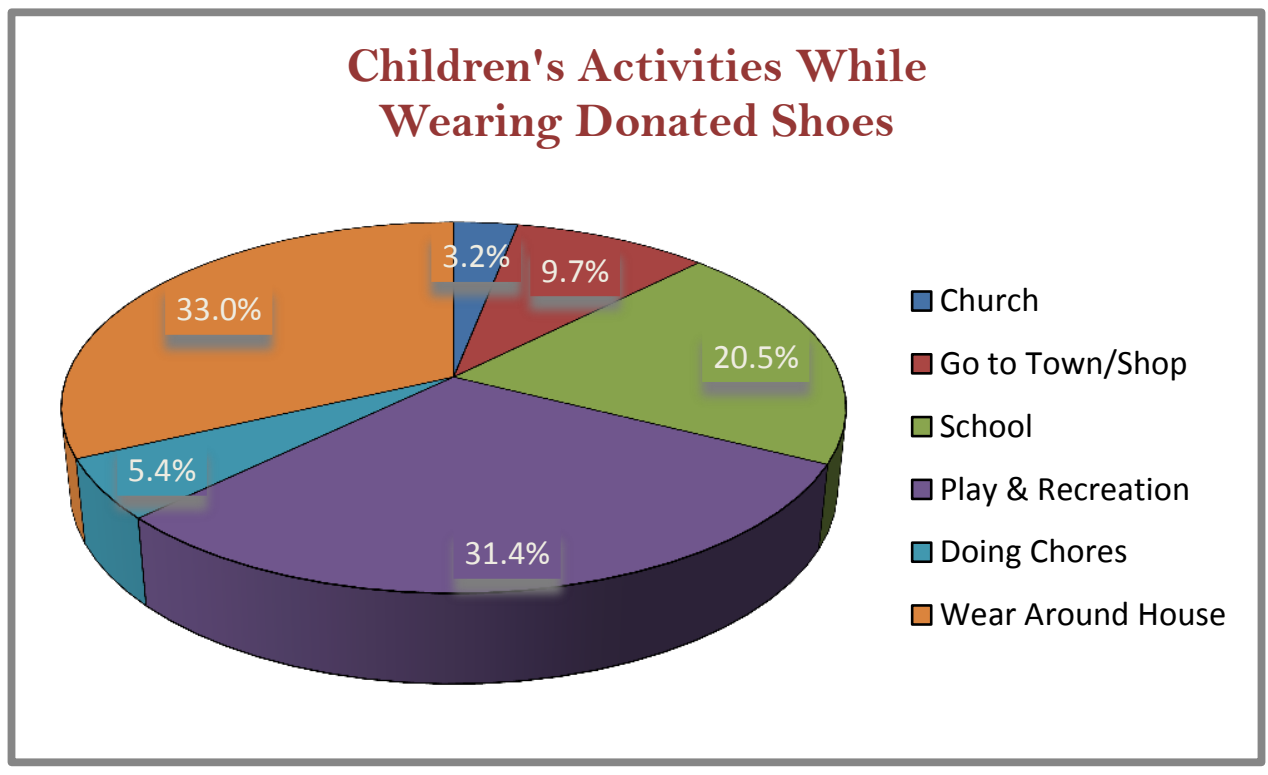

Figure 2: Breakdown of Children's Activities While Wearing Donated Shoes 


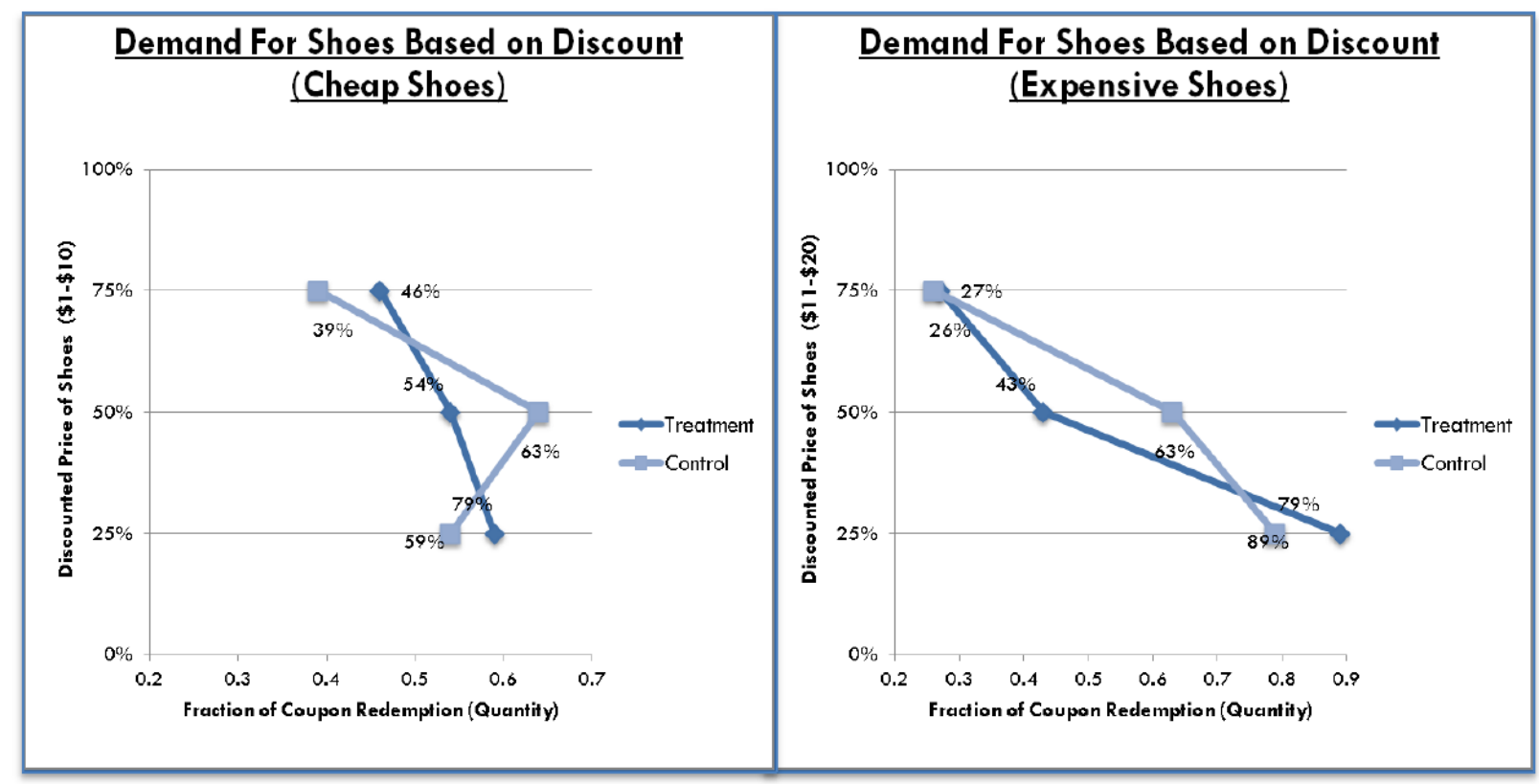

Figure 3: Demand Curve for Inexpensive and Expensive Shoes

*In ADPs 3 and 4 only. Based on assumption of 1/3 distribution of coupons between households. Source: Shevloff (2013). 
Table 1: Means of Control Variables and Balance Tests

\begin{tabular}{|c|c|c|c|c|c|}
\hline Variable & $\begin{array}{l}\text { Control } \\
\text { Mean }\end{array}$ & $\begin{array}{l}\text { Control } \\
\text { Std. Dev. }\end{array}$ & $\begin{array}{l}\text { Treatment } \\
\text { Mean }\end{array}$ & $\begin{array}{l}\text { Treatment } \\
\text { Std. Dev. }\end{array}$ & $p$-value \\
\hline \multicolumn{6}{|l|}{ Household Characteristics: } \\
\hline Parental Education & 4.8725 & 2.5146 & 4.7060 & 2.1114 & 0.2611 \\
\hline Log of Land Holdings & 7.9754 & 1.2539 & 8.0504 & 1.6526 & 0.4464 \\
\hline Electricity in House & 0.6875 & 0.4641 & 0.6732 & 0.4695 & 0.6355 \\
\hline Has Mobile Phone & 1.3744 & 0.9349 & 1.2977 & 0.9271 & 0.2035 \\
\hline Television in Household & 0.7609 & 0.4804 & 0.7041 & 0.5360 & 0.0881 \\
\hline Number Family Members & 5.4602 & 1.7605 & 5.3387 & 1.9556 & 0.3170 \\
\hline Household Age--Average & 22.7929 & 6.5586 & 23.3779 & 7.2831 & 0.1955 \\
\hline Minutes to Shoe Store & 98.8337 & 3.3871 & 98.8770 & 2.9132 & 0.8306 \\
\hline House has Dirt Floor & 0.6058 & 0.4893 & 0.6732 & 0.4695 & $0.0294 * *$ \\
\hline Number of Children $<10$ & 2.5144 & 0.0967 & 2.5239 & 0.0824 & 0.9400 \\
\hline $\begin{array}{l}\text { Baseline Shoe Purchase } \\
\text { ( } 6 \text { Months Before Baseline) }\end{array}$ & 0.265 & 0.442 & 0.245 & 0.430 & 0.3788 \\
\hline \multicolumn{6}{|l|}{ Coupon Redemption: } \\
\hline $\begin{array}{l}\text { Redeemed Cheap Shoes } \\
\text { Coupon }\end{array}$ & 0.3341 & 0.4723 & 0.3250 & 0.4688 & 0.7650 \\
\hline $\begin{array}{l}\text { Redeemed Expensive Shoes } \\
\text { Coupon }\end{array}$ & 0.3462 & 0.4763 & 0.3268 & 0.4695 & 0.5269 \\
\hline $\begin{array}{l}\text { Redeemed Cheap and/or } \\
\text { Expensive Shoes Coupon }\end{array}$ & 0.3942 & 0.4893 & 0.3730 & 0.4840 & 0.4997 \\
\hline $\begin{array}{l}\text { Redeemed Any Coupon } \\
\text { (Self Reported) }\end{array}$ & 0.4350 & 0.4963 & 0.3783 & 0.4854 & $0.0735^{*}$ \\
\hline
\end{tabular}

${ }^{* * *} p<0.01,{ }^{* *} p<0.05,{ }^{*} p<0.10$ 
Table 2: Impact on Purchases of Inexpensive Shoes $(<\$ 10)$

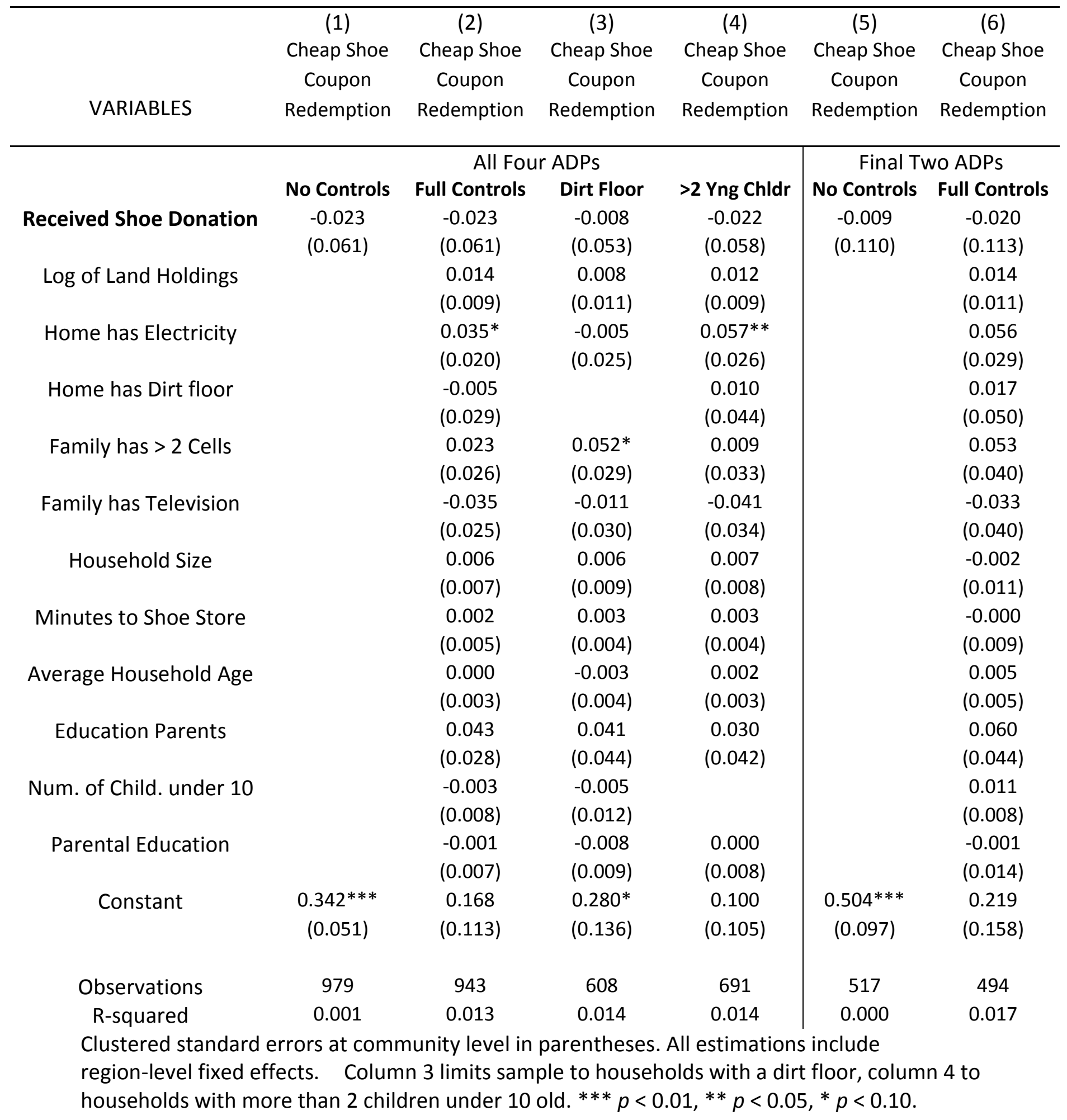


Table 3: Impact on Purchases of Expensive Shoes (>=\$10)

\begin{tabular}{|c|c|c|c|c|c|c|}
\hline VARIABLES & $\begin{array}{c}\text { (1) } \\
\text { Expensive } \\
\text { Shoe Coupon } \\
\text { Redemption }\end{array}$ & $\begin{array}{c}(2) \\
\text { Expensive } \\
\text { Shoe Coupon } \\
\text { Redemption }\end{array}$ & $\begin{array}{c}(3) \\
\text { Expensive } \\
\text { Shoe Coupon } \\
\text { Redemption }\end{array}$ & $\begin{array}{c}\text { (4) } \\
\text { Expensive } \\
\text { Shoe Coupon } \\
\text { Redemption }\end{array}$ & $\begin{array}{c}\text { (5) } \\
\text { Expensive } \\
\text { Shoe Coupon } \\
\text { Redemption }\end{array}$ & $\begin{array}{c}\text { (6) } \\
\text { Expensive } \\
\text { Shoe Coupon } \\
\text { Redemption }\end{array}$ \\
\hline & \multicolumn{4}{|c|}{ All Four ADPs } & \multicolumn{2}{|c|}{ Final Two ADPs } \\
\hline & No Controls & Full Controls & Dirt Floor & $>2$ Yng Chldr & No Controls & Full Controls \\
\hline Received Shoe Donation & $\begin{array}{c}-0.033 \\
(0.053)\end{array}$ & $\begin{array}{l}-0.022 \\
(0.056)\end{array}$ & $\begin{array}{c}-0.035 \\
(0.054)\end{array}$ & $\begin{array}{l}-0.060 \\
(0.054)\end{array}$ & $\begin{array}{l}-0.019 \\
(0.093)\end{array}$ & $\begin{array}{l}-0.022 \\
(0.105)\end{array}$ \\
\hline Log of Land Holdings & & $\begin{array}{c}0.008 \\
(0.013)\end{array}$ & $\begin{array}{l}-0.003 \\
(0.016)\end{array}$ & $\begin{array}{c}0.016 \\
(0.017)\end{array}$ & & $\begin{array}{c}0.008 \\
(0.018)\end{array}$ \\
\hline Home has Electricity & & $\begin{array}{c}0.013 \\
(0.038)\end{array}$ & $\begin{array}{l}-0.021 \\
(0.036)\end{array}$ & $\begin{array}{c}0.008 \\
(0.039)\end{array}$ & & $\begin{array}{l}-0.010 \\
(0.061)\end{array}$ \\
\hline Home has Dirt floor & & $\begin{array}{l}-0.049 \\
(0.031)\end{array}$ & & $\begin{array}{l}-0.028 \\
(0.038)\end{array}$ & & $\begin{array}{l}-0.063 \\
(0.051)\end{array}$ \\
\hline Family has $>2$ Cells & & $\begin{array}{l}-0.001 \\
(0.037)\end{array}$ & $\begin{array}{c}0.033 \\
(0.043)\end{array}$ & $\begin{array}{l}-0.004 \\
(0.041)\end{array}$ & & $\begin{array}{c}0.045 \\
(0.063)\end{array}$ \\
\hline Family has Television & & $\begin{array}{l}-0.012 \\
(0.030)\end{array}$ & $\begin{array}{c}0.001 \\
(0.040)\end{array}$ & $\begin{array}{l}-0.018 \\
(0.030)\end{array}$ & & $\begin{array}{c}0.008 \\
(0.047)\end{array}$ \\
\hline Household Size & & $\begin{array}{c}0.005 \\
(0.008)\end{array}$ & $\begin{array}{c}0.005 \\
(0.008)\end{array}$ & $\begin{array}{c}0.013 \\
(0.009)\end{array}$ & & $\begin{array}{c}0.007 \\
(0.013)\end{array}$ \\
\hline Minutes to Shoe Store & & $\begin{array}{c}0.003 \\
(0.004)\end{array}$ & $\begin{array}{c}0.004 \\
(0.004)\end{array}$ & $\begin{array}{c}0.002 \\
(0.004)\end{array}$ & & $\begin{array}{c}0.000 \\
(0.008)\end{array}$ \\
\hline Average Household Age & & $\begin{array}{c}0.002 \\
(0.003)\end{array}$ & $\begin{array}{c}0.002 \\
(0.004)\end{array}$ & $\begin{array}{c}0.003 \\
(0.003)\end{array}$ & & $\begin{array}{l}0.006^{*} \\
(0.003)\end{array}$ \\
\hline Education Parents & & $\begin{array}{c}0.027 \\
(0.026)\end{array}$ & $\begin{array}{c}0.036 \\
(0.029)\end{array}$ & $\begin{array}{c}0.016 \\
(0.029)\end{array}$ & & $\begin{array}{c}0.008 \\
(0.040)\end{array}$ \\
\hline Num. of Children under 10 & & $\begin{array}{c}0.004 \\
(0.009)\end{array}$ & $\begin{array}{c}0.010 \\
(0.013)\end{array}$ & & & $\begin{array}{c}0.017 \\
(0.010)\end{array}$ \\
\hline Parental Education & & $\begin{array}{c}0.001 \\
(0.005)\end{array}$ & $\begin{array}{c}-0.003 \\
(0.007)\end{array}$ & $\begin{array}{c}0.004 \\
(0.005)\end{array}$ & & $\begin{array}{c}0.000 \\
(0.010)\end{array}$ \\
\hline Constant & $\begin{array}{c}0.354 * * * \\
(0.044)\end{array}$ & $\begin{array}{c}0.171 \\
(0.130)\end{array}$ & $\begin{array}{c}0.193 \\
(0.132)\end{array}$ & $\begin{array}{c}0.073 \\
(0.160)\end{array}$ & $\begin{array}{c}0.527 * * * \\
(0.083)\end{array}$ & $\begin{array}{c}0.261 \\
(0.212)\end{array}$ \\
\hline Observations & 979 & 943 & 608 & 691 & 517 & 494 \\
\hline R-squared & 0.001 & 0.012 & 0.013 & 0.020 & 0.000 & 0.019 \\
\hline
\end{tabular}


Table 4: Impact on Purchases of All Shoes

\begin{tabular}{|c|c|c|c|c|c|c|}
\hline \multirow[t]{3}{*}{ VARIABLES } & $\begin{array}{c}(1) \\
\text { Any Shoe } \\
\text { Coupon } \\
\text { Redemption }\end{array}$ & $\begin{array}{c}(2) \\
\text { Any Shoe } \\
\text { Coupon } \\
\text { Redemption }\end{array}$ & $\begin{array}{c}(3) \\
\text { Any Shoe } \\
\text { Coupon } \\
\text { Redemption }\end{array}$ & $\begin{array}{c}\text { (4) } \\
\text { Any Shoe } \\
\text { Coupon } \\
\text { Redemption }\end{array}$ & $\begin{array}{c}\text { (5) } \\
\text { Any Shoe } \\
\text { Coupon } \\
\text { Redemption }\end{array}$ & $\begin{array}{c}(6) \\
\text { Any Shoe } \\
\text { Coupon } \\
\text { Redemption }\end{array}$ \\
\hline & \multicolumn{4}{|c|}{ All Four ADPs } & \multicolumn{2}{|c|}{ Final Two ADPs } \\
\hline & No Controls & Full Controls & Dirt Floor & $>2$ Yng Chldr & No Controls & Full Controls \\
\hline Received Shoe Donation & $\begin{array}{c}-0.037 \\
(0.064)\end{array}$ & $\begin{array}{c}-0.025 \\
(0.067)\end{array}$ & $\begin{array}{l}-0.024 \\
(0.063)\end{array}$ & $\begin{array}{l}-0.041 \\
(0.064)\end{array}$ & $\begin{array}{c}-0.029 \\
(0.115)\end{array}$ & $\begin{array}{l}-0.036 \\
(0.126)\end{array}$ \\
\hline Log of Land Holdings & & $\begin{array}{c}0.010 \\
(0.012)\end{array}$ & $\begin{array}{c}0.000 \\
(0.016)\end{array}$ & $\begin{array}{c}0.012 \\
(0.013)\end{array}$ & & $\begin{array}{c}0.012 \\
(0.014)\end{array}$ \\
\hline Home has Electricity & & $\begin{array}{c}0.019 \\
(0.035)\end{array}$ & $\begin{array}{l}-0.017 \\
(0.034)\end{array}$ & $\begin{array}{c}0.040 \\
(0.035)\end{array}$ & & $\begin{array}{c}-0.009 \\
(0.057)\end{array}$ \\
\hline Home has Dirt floor & & $\begin{array}{l}-0.027 \\
(0.029)\end{array}$ & & $\begin{array}{l}-0.001 \\
(0.039)\end{array}$ & & $\begin{array}{l}-0.041 \\
(0.050)\end{array}$ \\
\hline Family has $>2$ Cells & & $\begin{array}{c}0.010 \\
(0.034)\end{array}$ & $\begin{array}{c}0.038 \\
(0.040)\end{array}$ & $\begin{array}{c}0.006 \\
(0.042)\end{array}$ & & $\begin{array}{c}0.045 \\
(0.053)\end{array}$ \\
\hline Family has Television & & $\begin{array}{c}-0.008 \\
(0.033)\end{array}$ & $\begin{array}{c}0.001 \\
(0.034)\end{array}$ & $\begin{array}{c}-0.006 \\
(0.035)\end{array}$ & & $\begin{array}{c}0.029 \\
(0.056)\end{array}$ \\
\hline Household Size & & $\begin{array}{c}0.011 \\
(0.007)\end{array}$ & $\begin{array}{c}0.009 \\
(0.008)\end{array}$ & $\begin{array}{l}0.014 * \\
(0.008)\end{array}$ & & $\begin{array}{c}0.010 \\
(0.011)\end{array}$ \\
\hline Minutes to Shoe Store & & $\begin{array}{c}0.004 \\
(0.005)\end{array}$ & $\begin{array}{c}0.006 \\
(0.004)\end{array}$ & $\begin{array}{c}0.004 \\
(0.004)\end{array}$ & & $\begin{array}{c}-0.001 \\
(0.009)\end{array}$ \\
\hline Average Household Age & & $\begin{array}{c}0.001 \\
(0.003)\end{array}$ & $\begin{array}{l}-0.001 \\
(0.005)\end{array}$ & $\begin{array}{c}0.002 \\
(0.003)\end{array}$ & & $\begin{array}{c}0.004 \\
(0.004)\end{array}$ \\
\hline Education Parents & & $\begin{array}{c}0.046 \\
(0.030)\end{array}$ & $\begin{array}{c}0.054 \\
(0.038)\end{array}$ & $\begin{array}{c}0.035 \\
(0.040)\end{array}$ & & $\begin{array}{c}0.041 \\
(0.050)\end{array}$ \\
\hline Num. of Children under 10 & & $\begin{array}{l}-0.004 \\
(0.008)\end{array}$ & $\begin{array}{l}-0.001 \\
(0.012)\end{array}$ & & & $\begin{array}{c}0.003 \\
(0.009)\end{array}$ \\
\hline Parental Education & & $\begin{array}{l}-0.001 \\
(0.006)\end{array}$ & $\begin{array}{c}-0.006 \\
(0.007)\end{array}$ & $\begin{array}{c}0.001 \\
(0.006)\end{array}$ & & $\begin{array}{c}0.000 \\
(0.012)\end{array}$ \\
\hline Constant & $\begin{array}{c}0.403 * * * \\
(0.051)\end{array}$ & $\begin{array}{c}0.203 \\
(0.119)\end{array}$ & $\begin{array}{l}0.274^{*} \\
(0.137)\end{array}$ & $\begin{array}{c}0.091 \\
(0.136)\end{array}$ & $\begin{array}{c}0.593 * * * \\
(0.098)\end{array}$ & $\begin{array}{c}0.359 \\
(0.194)\end{array}$ \\
\hline Observations & 979 & 943 & 608 & 691 & 517 & 494 \\
\hline R-squared & 0.002 & 0.018 & 0.020 & 0.023 & 0.001 & 0.023 \\
\hline
\end{tabular}


Table 5: Impact on Purchases of All Shoes, Self Reported Data

\begin{tabular}{|c|c|c|c|c|c|c|}
\hline \multirow[t]{3}{*}{ VARIABLES } & $\begin{array}{c}(1) \\
\text { Any Shoe } \\
\text { Coupon } \\
\text { Redemption }\end{array}$ & $\begin{array}{c}(2) \\
\text { Any Shoe } \\
\text { Coupon } \\
\text { Redemption }\end{array}$ & $\begin{array}{c}(3) \\
\text { Any Shoe } \\
\text { Coupon } \\
\text { Redemption }\end{array}$ & $\begin{array}{c}\text { (4) } \\
\text { Any Shoe } \\
\text { Coupon } \\
\text { Redemption }\end{array}$ & $\begin{array}{c}\text { (5) } \\
\text { Any Shoe } \\
\text { Coupon } \\
\text { Redemption }\end{array}$ & $\begin{array}{c}(6) \\
\text { Any Shoe } \\
\text { Coupon } \\
\text { Redemption }\end{array}$ \\
\hline & \multicolumn{4}{|c|}{ All Four ADPs } & \multicolumn{2}{|c|}{ Final Two ADPs } \\
\hline & No Controls & Full Controls & Dirt Floor & $>2$ Yng Chldr & No Controls & Full Controls \\
\hline Received Shoe Donation & $\begin{array}{c}-0.070 \\
(0.064)\end{array}$ & $\begin{array}{c}-0.061 \\
(0.061)\end{array}$ & $\begin{array}{l}-0.070 \\
(0.058)\end{array}$ & $\begin{array}{c}-0.048 \\
(0.063)\end{array}$ & $\begin{array}{c}-0.071 \\
(0.111)\end{array}$ & $\begin{array}{c}-0.094 \\
(0.107)\end{array}$ \\
\hline Log of Land Holdings & & $\begin{array}{c}0.004 \\
(0.013)\end{array}$ & $\begin{array}{l}-0.003 \\
(0.018)\end{array}$ & $\begin{array}{c}0.006 \\
(0.012)\end{array}$ & & $\begin{array}{c}0.008 \\
(0.016)\end{array}$ \\
\hline Home has Electricity & & $\begin{array}{c}-0.044 \\
(0.028)\end{array}$ & $\begin{array}{c}-0.072 * * \\
(0.033)\end{array}$ & $\begin{array}{l}-0.006 \\
(0.027)\end{array}$ & & $\begin{array}{c}-0.112 * * * \\
(0.032)\end{array}$ \\
\hline Home has Dirt floor & & $\begin{array}{c}-0.057 * \\
(0.029)\end{array}$ & & $\begin{array}{l}-0.022 \\
(0.039)\end{array}$ & & $\begin{array}{l}-0.086 \\
(0.048)\end{array}$ \\
\hline Family has $>2$ Cells & & $\begin{array}{c}0.037 \\
(0.033)\end{array}$ & $\begin{array}{c}0.067 \\
(0.039)\end{array}$ & $\begin{array}{c}0.033 \\
(0.036)\end{array}$ & & $\begin{array}{c}0.047 \\
(0.047)\end{array}$ \\
\hline Family has Television & & $\begin{array}{c}0.033 \\
(0.031)\end{array}$ & $\begin{array}{c}0.045 \\
(0.038)\end{array}$ & $\begin{array}{c}0.046 \\
(0.029)\end{array}$ & & $\begin{array}{l}0.088^{*} \\
(0.041)\end{array}$ \\
\hline Household Size & & $\begin{array}{c}-0.004 \\
(0.008)\end{array}$ & $\begin{array}{l}-0.003 \\
(0.009)\end{array}$ & $\begin{array}{c}0.006 \\
(0.009)\end{array}$ & & $\begin{array}{c}-0.002 \\
(0.011)\end{array}$ \\
\hline Minutes to Shoe Store & & $\begin{array}{c}0.002 \\
(0.005)\end{array}$ & $\begin{array}{c}0.005 \\
(0.005)\end{array}$ & $\begin{array}{c}0.002 \\
(0.005)\end{array}$ & & $\begin{array}{c}-0.008 \\
(0.008)\end{array}$ \\
\hline Average Household Age & & $\begin{array}{c}0.003 \\
(0.003)\end{array}$ & $\begin{array}{c}0.001 \\
(0.004)\end{array}$ & $\begin{array}{c}0.002 \\
(0.003)\end{array}$ & & $\begin{array}{c}0.009 * * \\
(0.003)\end{array}$ \\
\hline Education Parents & & $\begin{array}{c}0.089 * * \\
(0.032)\end{array}$ & $\begin{array}{c}0.093 * * \\
(0.034)\end{array}$ & $\begin{array}{c}0.065 \\
(0.048)\end{array}$ & & $\begin{array}{l}0.112^{*} \\
(0.055)\end{array}$ \\
\hline Num. of Children under 10 & & $\begin{array}{c}0.004 \\
(0.010)\end{array}$ & $\begin{array}{c}0.008 \\
(0.012)\end{array}$ & & & $\begin{array}{c}0.016 \\
(0.012)\end{array}$ \\
\hline Parental Education & & $\begin{array}{c}0.004 \\
(0.005)\end{array}$ & $\begin{array}{c}-0.001 \\
(0.007)\end{array}$ & $\begin{array}{c}0.004 \\
(0.005)\end{array}$ & & $\begin{array}{c}0.006 \\
(0.009)\end{array}$ \\
\hline Constant & $\begin{array}{c}0.443 * * * \\
(0.048)\end{array}$ & $\begin{array}{c}0.314 * * \\
(0.149)\end{array}$ & $\begin{array}{l}0.312^{*} \\
(0.167)\end{array}$ & $\begin{array}{c}0.235 \\
(0.141)\end{array}$ & $\begin{array}{c}0.635^{* * *} \\
(0.089)\end{array}$ & $\begin{array}{l}0.455^{*} \\
(0.214)\end{array}$ \\
\hline Observations & 979 & 943 & 608 & 691 & 517 & 494 \\
\hline R-squared & 0.006 & 0.030 & 0.033 & 0.020 & 0.005 & 0.061 \\
\hline
\end{tabular}


Table 6: Impact on Purchases of All Shoes (Differences-in-Differences)

\begin{tabular}{|c|c|c|c|c|c|c|}
\hline VARIABLES & $\begin{array}{c}(1) \\
\text { New Shoes in } \\
\text { Last } 3 \text { Mo. }\end{array}$ & $\begin{array}{c}(2) \\
\text { New Shoes in } \\
\text { Last } 3 \text { Mo. }\end{array}$ & $\begin{array}{c}(3) \\
\text { New Shoes in } \\
\text { Last } 3 \text { Mo. }\end{array}$ & $\begin{array}{c}(4) \\
\text { New Shoes in } \\
\text { Last } 3 \text { Mo. }\end{array}$ & $\begin{array}{c}(5) \\
\text { New Shoes in } \\
\text { Last } 3 \text { Mo. }\end{array}$ & $\begin{array}{c}(6) \\
\text { New Shoes in } \\
\text { Last } 3 \text { Mo. }\end{array}$ \\
\hline & No Controls & Full Controls & Dirt Floor & $>2$ Yng Chldr & $\begin{array}{l}\text { Impact on } \\
\text { Siblings }\end{array}$ & $\begin{array}{l}\text { Impact on } \\
\text { Siblings }\end{array}$ \\
\hline RSD*Age6to12 & $\begin{array}{l}-0.041 \\
(0.070)\end{array}$ & $\begin{array}{l}-0.038 \\
(0.071)\end{array}$ & $\begin{array}{l}-0.028 \\
(0.070)\end{array}$ & $\begin{array}{l}-0.031 \\
(0.067)\end{array}$ & $\begin{array}{l}-0.058 \\
(0.072)\end{array}$ & $\begin{array}{l}-0.053 \\
(0.073)\end{array}$ \\
\hline RSD*Under6 & & & & & $\begin{array}{l}-0.055 \\
(0.034)\end{array}$ & $\begin{array}{l}-0.054 \\
(0.034)\end{array}$ \\
\hline RSD*Age13to19 & & & & & $\begin{array}{l}-0.024 \\
(0.028)\end{array}$ & $\begin{array}{l}-0.036 \\
(0.028)\end{array}$ \\
\hline Rec'd Shoe Donation & $\begin{array}{l}-0.019 \\
(0.027)\end{array}$ & $\begin{array}{c}-0.011 \\
(0.030)\end{array}$ & $\begin{array}{c}-0.033 \\
(0.026)\end{array}$ & $\begin{array}{c}-0.015 \\
(0.029)\end{array}$ & $\begin{array}{c}-0.002 \\
(0.023)\end{array}$ & $\begin{array}{c}0.004 \\
(0.027)\end{array}$ \\
\hline age6to12 & $\begin{array}{c}0.160 * * * \\
(0.052)\end{array}$ & $\begin{array}{c}0.120 * * \\
(0.053)\end{array}$ & $\begin{array}{l}0.115^{*} \\
(0.056)\end{array}$ & $\begin{array}{c}0.116^{* *} \\
(0.050)\end{array}$ & $\begin{array}{c}0.156 * * * \\
(0.051)\end{array}$ & $\begin{array}{c}0.162^{* *} \\
(0.057)\end{array}$ \\
\hline under6 & & & & & $\begin{array}{c}0.012 \\
(0.024)\end{array}$ & $\begin{array}{c}0.029 \\
(0.026)\end{array}$ \\
\hline age13to19 & & & & & $\begin{array}{c}0.075^{* * *} \\
(0.022)\end{array}$ & $\begin{array}{c}0.099 * * * \\
(0.020)\end{array}$ \\
\hline age & & $\begin{array}{c}-0.002^{* * *} \\
(0.000)\end{array}$ & $\begin{array}{c}-0.002 * * * \\
(0.000)\end{array}$ & $\begin{array}{c}-0.002^{* * *} \\
(0.000)\end{array}$ & $\begin{array}{c}-0.001 * * * \\
(0.000)\end{array}$ & $\begin{array}{c}-0.001 * * \\
(0.000)\end{array}$ \\
\hline hhshoebuy & & $\begin{array}{l}0.054^{* *} \\
(0.019)\end{array}$ & $\begin{array}{l}0.046^{*} \\
(0.023)\end{array}$ & $\begin{array}{l}0.045^{*} \\
(0.022)\end{array}$ & & $\begin{array}{c}0.054^{* *} \\
(0.019)\end{array}$ \\
\hline Constant & $\begin{array}{c}0.125^{* * *} \\
(0.020)\end{array}$ & $\begin{array}{c}0.196 * * \\
(0.090)\end{array}$ & $\begin{array}{c}0.202^{* * *} \\
(0.058)\end{array}$ & $\begin{array}{l}0.175^{*} \\
(0.097)\end{array}$ & $\begin{array}{c}0.142^{* * *} \\
(0.024)\end{array}$ & $\begin{array}{l}0.152^{*} \\
(0.087)\end{array}$ \\
\hline Observations & 5,046 & 4,816 & 3,150 & 3,775 & 5,037 & 4,816 \\
\hline R-squared & 0.033 & 0.053 & 0.051 & 0.049 & 0.045 & 0.059 \\
\hline
\end{tabular}

RSD = Received Shoe Donation. Clustered standard errors at community level in parentheses.

All estimations include region-level fixed effects. Column 3 limits sample to households with a dirt floor, column 4 to households with more than 2 children under 10 old. Regressions also include controls for electricity in household, dirt floor (except column 3), cell phone ownership, television, household size, minutes to shoe store, education of parents, number of young children (except column 4), and parental education. (None of these controls is statistically significant to $p<0.10$.) $* * * p<0.01, * * p<0.05, * p<0.10$. 


\section{Endnotes}

${ }^{1}$ See for example public criticisms such as Wadhams (2010), Nemana (2010), and Easterly (2012).

${ }^{2}$ Our registry can be viewed online at http://www.povertyactionlab.org/Hypothesis-Registry. Casey, Glennerster, and Miguel (2012) present a detailed exposition of the advantages of pre-analysis plans and hypothesis registry to development researchers. Hypothesis registry was particularly important in the case of our study, in which we investigate the impact of a donation program operated by a significant funder of our fieldwork with an interest in ascertaining the different impacts of its own program.

${ }^{3}$ The few minor changes to the specification of our estimations were made at the request of referees.

${ }^{4}$ This specification differs slightly from our hypothesis registry in that in our coupon experiment we use only follow-up data.

${ }^{6}$ We carry out our estimations using clustered standard errors at the community level. Because our number of communities offers a borderline case over which clustered standard errors are appropriate, we also carry out regressions (not shown) using robust standard errors which yield essentially identical results. 